\title{
Pola Sensitifitas dan Resistensi Kuman Urin, Ujung Kateter dan Ujung Drain Pasien Resipient Transplantasi Ginjal di RS PGI Cikini Jakarta
}

\author{
Etriyel Myh, David Manuputty
}

\begin{abstract}
Abstrak
Latar Belakang: Infeksi masih merupakan masalah pasca transplantasi ginjal. Infeksi tersering adalah infeksi saluran kemih. Penelitian ini untuk mengetahui angka kejadian infeksi saluran kemih, hasil kultur dan test sensitivitas resipient transplantasi ginjal di RS Cikini Jakarta. Metodologi: Merupakan penelitian deskriptif. Data diambil dari catatan hasil kultur dan uji sensitifitas urin, ujung kateter dan ujung drain resipien transplantasi ginjal yang terdapat di laboratorium mikrobiologi RS PGI Cikini Jakarta antara 1 january 1999 - 31 Desember 2009. Hasil : Dalam periode ini terdapat 72 pasien, dari 72 pasien data yang terkumpul sebanyak 54 pasien. 18 pasien lainnya nama dan data kulturnya tidak kami temukan di laboratoum mikrobiologi RS PGI Cikini. Semua pasien didapatkan memiliki hasil kultur positif pada salah satu bahan: urin, ujung kateter atau ujung drain. Kejadian hasil kultur positif pada sediaan urin $(61,11 \%)$, ujung kateter $(68,51 \%)$ dan ujung drain $(70,37 \%)$. Kuman paling sering dari urin adalah E. Coli $(14,8 \%)$, dari ujung kateter adalah $S$. Epidermidis $(16,3 \%)$ dan dari ujung drain $S$. Aureus $(16,3 \%)$. Antibiotik yang paling sensitif untuk infeksi dari urin dan ujung kateter adalah meropenem $(76,10 \%)$, dan (79\%), sedangkan untuk ujung drain adalah imipenem (76\%). Kesimpulan : Kuman tersering yang tumbuh pada sediaan urin adalah $E$. Coli sedangkan dari ujung kateter $S$ Epidermidis dan ujung drain $S$ Aureus. Meropenem adalah pilhan pertama untuk infeksi dari urin atau ujung kateter dan imipenem untuk infeksi dari ujung drain.
\end{abstract}

Kata kunci: Kultur: urin, ujung kateter dan ujung drain, resipient transplant

\begin{abstract}
Background: Infection is still problem among resipient kidney transplant. Urinary tract infection is the most common site of infection. The Aim is to Study incidence of urinary tract infection and studying sensitivity and resistace of bacteria from urine, catheter tip and tip of drain from recipient kidney transplant at Cikini Hospital Jakarta. Methods: This is descriptive study. Data from medical record of recipient kidney transplant and resistance and sensitivity data from microbiology Laboratory Cikini Hospital Jakarta. Results : There were 54 data from 72 patient's. Most of patient was man (74,1\%). All Of patient (100\%) with positive result from one of sample : urine, tip of catheter or tip of drain. Group of age 31-40 years is the most often group whose transplanted. Incidence of positive urine culture $(61,11 \%)$, tip of catheter (68,51\%) and tip of drain (70,37\%). The most common bacteria from urine was E. Coli (14,8\%) from tip of urine catheter was S. Epidermidis (16,3\%) and tip of drain S. Aureus (16,3\%). Most sensitive antibiotic from urine culture and tip of urine catheter was meropenem (76,10\%) and (79\%) and tip of drain was imipenem (89\%). Conclusions : The most common bacteria from urine was E. Coli, tip of urine catheter was $S$. Epidermidis and tip of drain was $S$ Aureus. Meropenem is the most sensitive antibiotic for urine infection and imipenem for infection from tip of drain.
\end{abstract}

Keywords: Culture of Urine, tip of urine catheter and tip of drain, recipient transplant of kidney

Affiliasi penulis : Bagian Urologi Fakultas Kedokteran Universitas Indonesia, Rumah Sakit PGI Cikini Jakarta.

Korespondensi : Etriyel Myh Bagian Urologi Fakultas Kedokteran Universitas Andalas RS DR M Djamil Padang.etriyelmyh@yahoo.com

\section{Pendahuluan}

Infeksi masih menjadi permasalahan pada pasien pasca transplantasi ginjal. Infeksi tersering adalah infeksi saluran kemih, infeksi luka operasi dan infeksi saluran napas. Insiden infeksi saluran kemih pasca transplantasi bervariasi dari $35 \%$ - $79 \%$. Tolkof et al melaporkan angka kejadian infeksi saluran kemih pasca transplantasi $30-40 \%{ }^{(1,2,3)}$. Kuman gram negatif merupakan penyebab utama infeksi saluran kemih $(76 \%)$ dan kuman gram negatif paling sering adalah E. Coli ( $33 \%$ ). Faktor resiko terjadinya infeksi saluran kemih paska transplantasi ginjal seperti: kateter uretra, trauma ureter dan ginjal selama operasi, jenis kelamin perempuan, kelaianan anatomi saluran kemih dan penggunaan immunosupresan ${ }^{(4)}$. Morbiditas dan mortalitas infeksi saluran kemih pada resipien berkaitan dengan infeksinya sendiri atau infeksi itu bisa menjadi pemicu munculnya reaksi rejeksi ${ }^{(5)}$. Sabin et al melaporkan angka kematian akibat infeksi pada resipient transplantasi ginjal 3, $5 \%$ pada 2 minggu pertama dan penyebab utamanya adalah infeksi saluran kemih ${ }^{(6)}$. Pemakaian kateter merupakan salah satu resiko terjadinya infeksi saluran kemih pasca transplantasi, Wareen et al mendapatkan kemungkinanan bakteremia 5-10 \% pada pasien resipien yang dipasang foley catheter walapun tidak diberikan obat immunosupresan dan dengan 
melepaskan kateter angka kejadian infeksi saluran kemih akan turun $15 \%$. ${ }^{(7)}$

Pada penelitian ini kami memaparkan hasil uji resistensi dan senstifitas dari sediaan urin, ujung kateter dan ujung drain, dengan data ini bisa dilihat kejadian infeksi saluran kemih pasca transplantasi dan dinilai juga hasil kultur ujung drain apakah berasal dari kuman yang sama yang tumbuh dari sediaan urin atau ujung kateter.

\section{Metode}

Studi retrospektif dengan desain deskriptif. Data diambil dari catatan rekam medis resipien transplantasi ginjal di RS PGI Cikini pada periode January 1999- 31 Desember 2009

Hasil

Terdapat 72 pasien yang dilakukan transplantasi ginjal di RS PGI Cikini pada periode penelitian.

Tabel 1: Dsitribusi frekuensi pasien resipient berdasarkan jenis kelamin

\begin{tabular}{llll}
\hline No & Jenis kelamin & Jumlah & $\%$ \\
\hline 1 & Laki-laki & 40 & 74,1 \\
2 & Perempuan & 14 & 25,9 \\
\hline TOTAL & & 54 & 100 \\
\hline
\end{tabular}

Tabel 2: Dsitribusi frekuensi pasien resipient berdasarkan umur

\begin{tabular}{llll}
\hline No & Umur & Jumlah & $\%$ \\
\hline 1 & $10-20$ & 2 & 3,7 \\
2 & $21-30$ & 12 & 22,2 \\
3 & $31-40$ & 16 & 29,6 \\
4 & $41-50$ & 14 & 25,6 \\
5 & $51-60$ & 10 & 18,5 \\
\hline TOTAL & & 54 & 100 \\
\hline
\end{tabular}

Tabel 3: Distribusi frekuensi kejadian kultur positif pada urin, ujung kateter atau ujung drain pasien resipien transplant

Kultur urin, ujung kateter atau ujung drain

\begin{tabular}{llll}
\hline Kultur positif & $\%$ & Kultur negatif (-) & $\%$ \\
\hline 54 & 100 & 0 & 0
\end{tabular}

Tabel 4 : Distribusi frekuensi kejadian kultur urin, ujung kateter dan ujung drain

Hasil kultur positif

\begin{tabular}{lll}
\hline Urin & Ujung kateter & Ujung drain \\
\hline $33(61,11 \%)$ & $37(68,51 \%)$ & $38(70,37 \%)$ \\
\hline
\end{tabular}

Tabel 5 : Hasil kultur urin pasien resipient transplant.

\begin{tabular}{llll}
\hline No & Kuman hasil kultur & Jumlah & $\%$ \\
\hline 1 & E.Coli & 8 & 14.8 \\
2 & A Streptococus & 3 & 5.6 \\
3 & Streptococus B Hemolitycus & 3 & 5,6 \\
4 & S.Epidermidis & 2 & 3.7 \\
5 & Enterobacter Cloaca & 2 & 3.7 \\
6 & C. Frendii & 2 & 3.7 \\
7 & Pseudomonas flouresent & 2 & 3.7 \\
8 & Staphylococus aureus & 1 & 1.9 \\
9 & Pseudomonas sp & 1 & 1.9 \\
10 & Enterobacter aglomerans & 1 & 1.9 \\
11 & Eschericia sp & 1 & 1.9 \\
12 & Klebsiela Ozeana & 1 & 1.9 \\
13 & Enterobacter aerogenes & 1 & 1.9 \\
14 & Acinobacter anitrans & 1 & 1.9 \\
15 & Klebsiela oxytica & 1 & 1.9 \\
16 & tidak tumbuh & 24 & 44.4 \\
\hline & Total & $\mathbf{5 4}$ & $\mathbf{1 0 0 . 0}$ \\
\hline \multirow{2}{*}{1} & & &
\end{tabular}

Tabel 6 : Hasil kultur ujung kateter pasien resipient transplant

\begin{tabular}{llcc}
\hline No & Kuman hasil kultur & Jumlah & $\%$ \\
\hline 1 & Staphylococus & 9 & 16,3 \\
& epidermidis & & \\
2 & E. Coli & 6 & 10,90 \\
3 & Klebsiella Pneumonia & 4 & 7,27 \\
4 & Enterobacter aerogenes & 3 & 5.45 \\
5 & A. Streptococus & 3 & 5.45 \\
6 & Staphylococus aureus & 3 & 5.45 \\
7 & strepto ccous B & 3 & 5.45 \\
& hemolyticus & & \\
8 & Klebsile ozeana & 2 & 3,63 \\
9 & Enterobacter ferendii & 1 & 1.8 \\
10 & eschrecia sp & 1 & 1.8 \\
11 & Enterobacter Cloaca & 1 & 1.8 \\
12 & Enterobacter gergovae & 1 & 1.8 \\
13 & tidak tumbuh & 18 & 32.72 \\
\hline & Total & $\mathbf{5 5}$ & $\mathbf{1 0 0 . 0}$ \\
\hline & & & \\
\hline
\end{tabular}




\begin{tabular}{|c|c|c|c|}
\hline No & Kuman hasil kultur & Jumlah & $\%$ \\
\hline 1 & Staphylococus aereus & 9 & 16,3 \\
\hline 2 & Staphylococus epidermidis & 8 & 14.54 \\
\hline 3 & Klebsiela ozeana & 3 & 5.45 \\
\hline 4 & Pseudomonas flouresent & 3 & 5.45 \\
\hline 5 & Klebsiella oxyotica & 2 & 3,63 \\
\hline 6 & Klebsiella pneumonia & 2 & 3,63 \\
\hline 7 & A.Streptococus & 2 & 3,63 \\
\hline 8 & Pseudomonas sp & 2 & 3,63 \\
\hline 9 & Acinobacter anitrans & 2 & 3,63 \\
\hline 10 & Enterobacter frendii & 1 & 1.8 \\
\hline 11 & Klebsiela sp & 1 & 1.8 \\
\hline 12 & Pseudomonas aerogenes & 1 & 1.8 \\
\hline 13 & C. Frendii & 1 & 1.8 \\
\hline 14 & E. Coli & 1 & 1.8 \\
\hline 15 & S. Higne faciens & 1 & 1.8 \\
\hline \multirow[t]{2}{*}{16} & tidak tumbuh & 16 & 29.096 \\
\hline & Total & 55 & 100.0 \\
\hline
\end{tabular}

Tabel 8: Persentase kuman urin, ujung kateter dan ujung drain berdasarkan pewarnaan gram

\begin{tabular}{lll}
\hline Bahan & Gram negative & Gram positif \\
\hline Urin & $24(80 \%)$ & $6(20 \%)$ \\
Ujung kateter & $19(51 \%)$ & $18(49 \%)$ \\
Ujung drain & $19(49 \%)$ & $20(51)$ \\
\hline
\end{tabular}

Tabel 9: Hasil uji senstifitas kuman urin

\begin{tabular}{llc}
\hline No & Antbiotik & $\begin{array}{c}\text { Persentase kumulatif } \\
\text { yang sensitive }\end{array}$ \\
\hline 1 & Meropenem & $76,10 \%$ \\
2 & Imipenem & $73,50 \%$ \\
3 & Fosmycin & $47,90 \%$ \\
4 & Amikiasin & $42,00 \%$ \\
5 & Gentamycin & $36,90 \%$
\end{tabular}

$\begin{array}{lll}6 & \text { Tercoplanin } & 34,75 \% \\ 7 & \text { Cotrimoksazol } & 33,00 \% \\ 8 & \text { Cefotoxime } & 28,60 \% \\ 9 & \text { Ceftriaxone } & 25,50 \% \\ 10 & \text { Ceftazidime } & 25,40 \%\end{array}$

Tabel 10: Hasil uji senstifitas ujung kateter

\begin{tabular}{llc}
\hline No & Antbiotik & $\begin{array}{c}\text { Persentase kumulatif } \\
\text { yang sensitive }\end{array}$ \\
\hline 1 & Meropenem & $79 \%$ \\
2 & Imipenem & $76 \%$ \\
3 & Amikiasin & $74 \%$ \\
5 & Cotrimoksazol & $55 \%$ \\
6 & Fosmycin & $51 \%$ \\
7 & Ciprofloxacin & $51 \%$ \\
8 & Tercoplanin & $46 \%$ \\
9 & Cloramfenikol & $41 \%$ \\
10 & Ampisilin sulbactam & $35 \%$ \\
\hline
\end{tabular}

Tabel 11: Hasil uji senstifitas kuman ujung drain

\begin{tabular}{llc}
\hline No & Antbiotik & $\begin{array}{c}\text { Persentase kumulatif yang } \\
\text { sensitive }\end{array}$ \\
\hline 1 & Imipenem & $89 \%$ \\
2 & Meropenem & $75 \%$ \\
3 & Amikiasin & $66 \%$ \\
4 & Fosmycin & $44 \%$ \\
5 & Cloramfenikol & $32 \%$ \\
6 & Ciprofloxacin & $31 \%$ \\
7 & Gentamycin & $30 \%$ \\
8 & Tercoplanin & $27 \%$ \\
9 & Ceftazidime & $27 \%$ \\
10 & Cotrimoksazol & $25 \%$ \\
\hline
\end{tabular}


Diskusi

Dari penelitian ini didapatkan sebagian besar transplantasi ginjal pada laki-laki (40 \%) dengan kelompok umur terbanyak antara 31-40 tahun. Seluruh pasien memiliki hasil kultur positif dari salah satu bahan urin, ujung kateter atau ujung drain. Hasil kultur positif urin $(61,11 \%)$ ujung kateter $(68,51 \%)$ dan ujung drain $(70,37 \%)$ pasien, hasil ini sesuai dengan kepustakaan yang melaporkan kejadian infeksi saluran kemih pasca transplantasi bervariasi anatara 35-79\% (2). Kuman gram negatif merupakan kuman yang paling sering dari sediaan urin dan ujung kateter $(80 \%)$ dan $(51 \%)$ sedangkan dari ujung drain adalah kuman gram positif ( $51 \%$ ). Kuman gram negatif paling sering yang tumbuh dari biakan urin adalah $E$. Coli ( $14,8 \%$ ) hasil ini sesuai dengan yang dilaporkan Sabin bahwa 29-60 \% infeksi saluran kemih paska tranplantasi disebabkan oleh $E$. Coli ${ }^{(6)}$. Nastor et al juga melaporkan infeksi saluran kemih pasca transplantasi pada hari 0-30 disebabkan bakteri golongan enterobactericea ${ }^{(8)}$.

Kuman yang paling sering tumbuh dari biakan ujung kateter adalah $S$ Epidermidis (16,3\%). Patogenesis terjadinya infeksi karena pemasangan kateter adalah masuknya kuman melalui kateter mulai hari pertama pemasangan kateter. S. Epidermidis merupakan kuman gram positif kulit dan jarang menyebabkan infeksi saluran kemih, Luiz et al melaporkan $90 \%$ resipien transplantasi ginjal terdapat kuman gram positif pada meatus uretranya. Jadi kemungkinan $S$. Epidermidis ini masuk dari orificium uretra externa saat pemasangan kateter yang bisa disebabkan tindakan antiseptik daerah genitalia eksterna yang belum efektif ${ }^{(9)}$.

Hasil kultur positif dari ujung drain pada 70,37 $\%$ pasien, sebagian besar ( $51 \%$ ) adalah kuman gram positif dan yang paling sering tumbuh adalah $S$ .Aureus $(16,3 \%)$. $S$ Aureus merupakan kuman kulit, dari penelitian ini didapatkan persentase kultur positif S. Aureus dari sediaan urin hanya $1,9 \%$ dan dari ujung kateter 5,45 \% sehingga kemungkinan besar kuman ini berasal dari kulit bukan dari leakage urin pada anastomosis ureter. Hal ini sesuai dengan kepustakaan yang mendapatkan bahwa infeksi kulit dan infeksi luka operasi paska transplantasi ginjal paling sering disebabkan $S$. aureus ${ }^{(8,10)}$.

Dari hasil uji sensitifitas didapatkan antibiotik yang paling sensitif untuk infeksi dari urin atau ujung kateter adalah meropenem sedangkan untuk kuman dari ujung drain adalah imipinem. Meropenem dan imipenem merupakan antibiotik golongan beta laktam yang efektif untuk bakteri gram negatif maupun gram positif, namun jika dibandingkan meropenem lebih efektif untuk kuman gram negatif sedangkan imipenem lebih efektif untuk bakteri gram positif. Data yang didapatkan pada penelitian ini sesuai dengan kepustakaan dimana meropenem lebih efektif untuk infeksi saluran kemih yang sebagian besar disebabkan kuman gram negatif sedangkan untuk kuman dari ujung drain imipinem lebih efektif karena sebagian besar disebabkan kuman gram positif ${ }^{(11)}$.

\section{Kesimpulan}

Kuman tersering yang tumbuh pada sediaan urin adalah $E$. Coli sedangkan dari ujung kateter $S$ Epidermidis dan ujung drain $S$ Aureus. Meropenem adalah pilihan pertama untuk infeksi dari urin atau ujung kateter sedangkan untuk infeksi dari ujung drain pilihan pertamanya adalah imipenem.

\section{Daftar pustaka}

1. Barry M.J, Jordan M.L, Conlin J.M. Renal Transplantation. In: Wein A.J, Kavoussu L.R, Novick N.C, Partin .A.W, Peters C.A , Editors. Campbell-walsh Urology $.9^{\text {th }}$ ed. Philadelphia : Sounders Elsevier.2007.P. 1295-1324 .

2. Dentas S.R.P.E, Kuboyama R.H, Mazzali M, Moretti.M.L. Nosocomial infection in renal transplant: risk factors and treatment implications associated with urinary tract and surgical site infection. Journal of Hospital Infection 2006;63:117-123.

3. Satish R, Gokulnath. Intractable Urinary Tract Infection in a Renal transplantation Recipient. Saudi J.Kidney Dis Transpl 2009;20:458-61.

4. Pinheiro.H.S, Mituiassu.A.M, Carminatti $M$, Braga A.M, Bastos M.G. Urinary tract infection caused by extende-spectrum Beta Lactamase producing Bacteria in kidney transplant Patinets.Transplanatation Proceedings 2010;42: 486-7.

5. Johnson J.R, Johnston B, Clabots C, Kuskowski M.A, Pendyala S, Debroy C, et al. Eccherichia coli sequence Type ST131 as an Emerging Flouroquinolone - resistant Uropathogen amon renal transplant recipients. Antimicrobial Agent $s$ and Chemotherapy 2010;54: 546-50.

6. Schamaldients S, Dittrich E, Horl.W.H. Urinary tract Infection after renal transplantation. Cuurent opinion in Urology 2002;12:125-30.

7. Boalke E, Jehle M.P, Stork M, Orth K, Schams $S$, Abendroth D. Urinary endotoxin excretion and urinary tract infection following kidney transplantation. Transpl Int 2001;14:307-10.

8. Varon F.N, Alangaden J.G. Emerging trends in infections among renal transplant recipients. Expert Rev.Anti-Infec.2004;2:95-109.

9. Oliveira LC, Lucon M.A, Nahas C.W, lanhez L.E, Arap S. Catheter- associated urinary infection in kidney post -transplant patients. Sao Paulo Med J 200;199:165-8.

10. Ada.S, Seckin.D, Azap O, Budakoglut, Haberal M. Prevalence of cutaneous bacterial infections and nasal carriage of Staphylococus aureus in recipients of renal transplants.Clinical and Expereimental dermatology2008;34:156-160.

11. American Society of health -System Pharmacists. AHFS drug information.2006. 